\title{
APLIKASI PUPUK ORGANIK KANDANG AYAM dan KONSENTRASI AIR KELAPA TERHADAP PERTUMBUHAN dan HASIL TANAMAN ERCIS (Pisum sativum L)
}

\author{
Riduan Sembiring ${ }^{1)}$, Sumatera Tarigan ${ }^{2)}$, dan Meriksa Sembiring ${ }^{3)}$ \\ ${ }^{1,2,3)}$ Dosen Fakultas Pertanian Universitas Quality \\ Email : bukti.rj@gmail.com
}

\begin{abstract}
ABSTRAK
Penelitian ini dilakukan di lahan Petani Desa Tigapanah, Kecamatan Tigapanah, Kabupaten Karo, dari bulan Maret hingga Juni 2016, ketinggian tempat \pm 1200 meter di atas permukaan laut, jenis tanah Adosol. Tujuan penelitian untuk menentukan dosis kotoran ayam dan konsentrasi air kelapa serta interaksinya dengan pertumbuhan dan hasil tanaman Ercis (Pisumsativum L). Rancangan Kelompok Acak Kelompok (RAK) faktorial 4 tingkat, faktor I: perolehan dosis 1) tanpa pupuk kandang (kontrol) 2) kotoran ayam 2) $200 \mathrm{~g} /$ tanaman, 3) $300 \mathrm{~g} /$ tanaman, 4) $400 \mathrm{~g} /$ tanaman (A0, A1 , A2, dan A3). Faktor II. Konsentrasi air kelapa 4 level 1) $0 \mathrm{ml} /$ tanaman, 2) $100 \mathrm{ml} /$ tanaman, 3) $200 \mathrm{ml} /$ tanaman, 4) $300 \mathrm{ml} /$ tanaman $(\mathrm{K} 0, \mathrm{~K} 1, \mathrm{~K} 2, \mathrm{~K} 3)$. Hasil penelitian pengaruh penggunaan kotoran ayam berbeda nyata $(\mathrm{p}>0,05)$ terhadap pertumbuhan tinggi tanaman, jumlah cabang, polong dan bobot tanaman Ercis kecuali bahwa umur mulai berbunga. Pemberian dosis air kelapa juga memberikan efek yang berbeda nyata $(\mathrm{p}>0,05)$ pada pertumbuhan tinggi tanaman, jumlah cabang, produksi polong dan bobot produksi kecuali usia mulai berbunga. Interaksi dosis pupuk kandang ayam dan dosis air kelapa tidak berpengaruh signifikan terhadap semua parameter yang diamati.
\end{abstract}

Kata kunci: pupuk ayam, air kelapa, arcis

\begin{abstract}
The research was carried out in the Tigapanah Village Farmers' field, Tigapanah Subdistrict, Karo Regency, from March to June 2016, where altitude was \pm 1200 meters above sea level, Adosol land. The aim of the study was to determine the chicken manure dosage and the concentration of coconut water and its interaction with the growth and yield of Ercis plants (Pisumsativum L). Factorial Randomized Group Design (RBD) 4 levels, factor I: dose acquisition 1) without manure (control) 2) chicken manure 2) $200 \mathrm{~g}$ / plant, 3) $300 \mathrm{~g} /$ plant, 4) $400 \mathrm{~g} /$ plant (AO , A1, A2, and A3). Factor II. Concentration of coconut water 4 level 1) $0 \mathrm{ml} /$ plant, 2) $100 \mathrm{ml} /$ plant, 3) $200 \mathrm{ml} /$ plant, 4) $300 \mathrm{ml} /$ plant $(K 0, K 1, K 2, K 3)$. The results of the study showed that the effect of using chicken manure was significantly different $(p>0.05)$ on the growth of plant height, number of branches, pods and weights of Ercis plants except that the age began to flower. Giving a dose of coconut water also gave a significantly different effect $(p>0.05)$ on the growth of plant height, number of branches, production of pods and production weights except age began to flower. The interaction of doses of chicken manure and doses of coconut water did not have a significant effect on all observed parameters.
\end{abstract}

Keywords: chicken fertilizer, coconut water, arcis 


\section{Pendahuluan}

Ercis atau kacang kapri (Pisum sativum L) tanaman Famili Fabaceae (polongpolongan), sayuran berupa buah dan biji yang berwarna hijau. Kacang dibawa Belanda ke Indonesia dalam bahasa Belanda disebut "erwtjes" artinya kacang kecil (Anonimous. 2010; Peternak,Petani,Nelayan, 2011).

Hasil observasi lapangan daerah produksi tanaman Arcis di Indonesia tumbuh baik di Jawa Barat dan Jawa Timur. Selain kedua daerah ini, di daerah Sumatera juga Arcis dapat dibudidayakan pertumbuhan yang baik di daerah Kabupaten Karo (Estu dan Nur. 1994: dan Rukmana, 2003).

Tanaman ini dapat bersimbiosis dengan bakteri Rhizobium, yang dapat mengikat Nitrogen bebas dari udara. Oleh karena itu, dalam budidaya tanaman kapri, pupuk Nitrogen hanya dibutuhkan pada permulaan tanam dalam jumlah yang sedikit. Selain itu, tanaman ini juga dapat meningkatkan kesuburan tanah, terutama kandungan Nitrogen (dalam bintil akar tanaman) yang tersedia dalam tanah (Rukmana, 2006)

Selanjutnya Kristina dan Syahid (2012) menyatakan air kelapa mengandung vitamin dan mineral. Hasil analisismenunjukkan bahwa air kelapa tua dan muda memiliki komposisi vitamin dan mineral yang berbeda. Menurut Pamungkas dkk. (2009) auksin akan membantu sel untuk membelah secara cepat dan berkembang menjadi tunas dan batang. Selain mengandung auksin dan sitokinin air kelapa juga terhadap pertumbuhan dan hasil tanaman ercis (Pisum sativum $\mathrm{L}$ ).

\section{Hipotesa Penelitian:}

Ada pengaruh nyata dosis pupuk kandang ayam cair dan konsentrasi air kelapa serta interaksi dosis pupuk kandang ayam cair dan konsentrasi air kelapa terhadap pertumbuhan dan hasil tanaman ercis (Pisum sativum L). mengandung nutrisi yang dibutuhkan oleh tanaman. Ketersediaan nutrisi bagi tanaman sangat penting untuk proses pertumbuhan.

Salah satu pupuk alami yang dapat meningkatan pertumbuhan vegetatif tanaman adalah air kelapa muda. Air kelapa merupakan cairan endosperm buah kepala yang mengandung senyawa-senyawa biologi yang aktif. Menurut Winarto dkk. (2015:304).

Agampodi dan Jawawardena (2009:280) melaporkan bahwa air kelapa mengandung ZPT yang digunakan dalam kultur jaringan dapatmeningkatkan inisiasi kalus dan perkembangan akar.

Berdasarkan analisis hormon yang dilakukan oleh Savitri (2005, dalam Djamhuri, 2011:5) ternyata dalam air kelapa muda mengandung hormongiberelin $(0,460 \mathrm{ppm}$ GA3, 0,255 ppmGA5, 0,053 ppm GA7), sitokinin $(0,441 \mathrm{ppm}$ kinetin, $0,247 \mathrm{ppm}$ zeatin), dan auksin (0,237 ppm IAA). Menurut Kristina dan Syahid (2012:126) air kelapa juga mengandung kadar kalium sebanyak 14,11 mg/100 ml, kalsium sebanyak 24,67 mg/100 ml,dan nitrogen sebanyak 43,00 mg/100 ml air kelapa muda. Air kelapa dapat meningkatkan pertumbuhan tanaman.

\section{Tujuan Penelitian}

untuk mengetahui dosis pupuk kandang ayam, konsentrasi air kelapa dan interaksi dosis pupuk kandang ayam dan konsentrasi air kelapa

\section{Kegunaan Penelitian:}

Untuk Mendapatkan data bahan penulisan Jurnal Agrotechnosains yang dikelola oleh LPPM Universitas Quality. Sebagai bahan informasi bagi petani, produsen dalam usaha untuk meningkatkan produksi tanaman ercis (Pisum sativum L). 
Agroteknosains/Vol.3/No. 02/November 2019/p-ISSN: 2598-6228/ e-ISSN : 2598-009

Metode Penelitian : Penelitian di kebun petani Desa Tigapanah Kecamatan Tigapanah Kabupaten Karo, ketinggian \pm 1200 meter dpl, tanah andosol dan dilaksanakan sejak bulan Maret - Juni 2016.

\section{Bahan dan Alat}

\section{Bahan Penelitian :}

Benih ercis, pupuk kandang ayam cair, EM 4, Air kelapa, insektisida, fungsida. Alat, digunakan adalah cangkul, bambu, timbangan, garu, cat, kuas, gelas, hands sprayer, alat-alat tulis, tripleks, meteran, kamera, pisau, tong, rol ajir dan tali rafia.

Metode Penelitian: Rancangan Acak Kelompok (RAK) Faktorial dua faktor: Faktor I: Dosis pupuk kandang ayam simbol "A" dengan 4 taraf, yaitu : Ao = Kontrol (tanpa pupuk), $\mathrm{A}_{1}=200$ gr/tanaman, $\mathrm{A}_{2}=300 \mathrm{gr} / \mathrm{tanaman}$ dan $\mathrm{A}_{3}=$ 400 gr/tanaman. Faktor II: Konsentrasi air kelapa simbol "K" dengan 4 taraf, yaitu : $\mathrm{Ko}=$ Air bersih, $\mathrm{K}_{1}=100 \mathrm{ml} /$ tanaman, $\mathrm{K}_{2}$ $=200 \mathrm{ml} /$ tanaman, $\mathrm{K}_{3}=300 \mathrm{ml} /$ tanaman.

Dengan kombinasi: $\mathbf{A}_{\mathbf{0}} \mathbf{K}_{\mathbf{0}}, \mathbf{A}_{\mathbf{2}} \mathbf{K}_{\mathbf{0}}, \mathbf{A}_{\mathbf{0}} \mathbf{K}_{\mathbf{1}}$, $A_{2} K_{1}, A_{0} K_{2}, A_{2} K_{2}, A_{0} K_{3}, A_{2} K_{3}, A_{1} K_{0}$, $A_{3} K_{0}, A_{1} K_{1}, \quad A_{3} K_{1}, A_{1} K_{2}, A_{3} K_{2}, A_{1} K_{3}$, $\mathbf{A}_{3} \mathbf{K}_{3}$. Jarak tanam $=20 \times 50 \mathrm{~cm}$, Jumlah tanaman per plot $=25$ tanaman, Jumlah ulangan $=3$ ulangan, Ukuran plot $=1 \mathrm{~m} \mathrm{x}$ $2,5 \mathrm{~m}$, Jumlah plo $=48$ plot, Jarak antar plot $=50 \mathrm{~cm}$, Jarak antar ulangan $=100$ $\mathrm{cm}$, Jumlah sampel per plot $=5$ tanaman, Jumlah tanaman sampel $=240$ tanaman dan, Luas areal $=200 \mathrm{~m}^{2}$, Jumlah tanaman seluruhnya $=1200$ tanaman

\section{Metode Analisa Data}

Metode analisa data yang digunakan adalah sebagai berikut:

$$
\mathbf{Y}_{\mathrm{ijk}}=\mu+\rho_{\mathrm{i}}+\alpha_{\mathrm{j}}+\beta_{\mathrm{k}}+(\alpha \beta)_{\mathrm{jk}}+\Sigma_{\mathrm{ijk}}
$$

Dimana:

Yijk = Hasil pengamatan percobaan dalam kelompok ke-i mendapat perlakuan dosis pupuk kandang cair pada taraf ke-j dan perlakuan air kelapa pada taraf ke $-\mathrm{k}$

$\mu \quad=$ Rata-rata nilai tengah perlakuan

$\rho_{\mathrm{i}} \quad=$ Efek kelompok ke-i $\alpha_{j}=$ Efek perlakuan dosis pupuk

kandang ayam cair pada taraf ke-j

$\beta_{\mathrm{k}}=$ Efek dari perlakuan air kelap pada taraf ke-k

$$
(\alpha \beta)_{\mathrm{jk}}
$$

Efek interaksi perlakuan dosis pupuk kandang cair pada taraf ke-j dan perlakuan dosis air kelapa pada taraf ke-k

$\Sigma \mathrm{ij}=$ Efek galat pada unit percobaan pada kelompok ke-I yang mendapat pemberian dosis pupuk kandang ayam cair taraf ke-j dan pemberian dosis air kelapa pada taraf ke-k.

\section{Pelaksanaan Penelitian}

Lahan dibersihkan dari rumput atau tanaman liar dicangkul atau dibajak dengan kedalaman $30 \mathrm{~cm}$, digemburkan kemudian diratakan. Selanjutnya pembuatan Plot-plot dengan ukuran tingginya $30 \mathrm{~cm}$, jarak antar plot $50 \mathrm{~cm}$, jarak ulangan $100 \mathrm{~cm}$.

Penanaman, lubang ditugal $\pm 5 \mathrm{~cm}$, benih ditabur di tutup kembali dengan tanah. jarak tanam $20 \mathrm{~cm} \times 50 \mathrm{~cm}$.

Penyiraman, tergantung cuaca, bila tidak hujan disiram tiap pagi dan sore hari.

Penyulaman, mengganti tanaman yang mati, terserang hama, penyakit dengan cepat, agar tanaman tetap seragam. 3 hst. Bahan taanaman dari tanaman pinggir.

Pemupukan, pemberian pupuk tersebut dilakukan sesuai dengan kebutuhan tanaman, dengan dosis dan interval yang sesuai.

Perlakuan pupuk kandang ayam, telebih dahulu di fermentasi selama 1 minggu dengan menggunakan EM4. Pemberian pupuk kandang ayam dilakukan selama 4 minggu dengan interval waktu 1 minggu sekali, sesuai dengan taraf perlakuan

Perlakuan air kelapa, air kelapa terlebih dahulu kumpulkan dalam wadah tong, difermentasikan selama 1 minggu sebelum pengecoran. Pemberian air kelapa pada saat tanam seminggu sesudah tumbuh sesuai perlakuan.

Penyiangan dan Pembumbunan, Penyiangan untuk mengendalikan gulma sekaligus untuk menggemburkan tanah. Penyiangan mencabut atau mengunakan 
alat bantu, sekaligus pembumbunan agar tanaman tidak mudah tumbang dan kokoh.

Pengendalian Hama Dan Penyakit, di kendalikan dengan pemberian insektisida dan penyakit dengan fungisida, dilakukan pengamatan, jika tidak ada serangan hama dan penyakit maka tidak dilakuan. Panen kapri polong muda dilakukan ketika umur tanaman mencapai 60- 70 hari.

\section{Parameter Yang Diamati}

Pengamatan tanaman sampel secara acak /plot, 5 tanaman, diamati: Tinggi tanaman (cm), jumlah cabang, umur berbunga (hari), jumlah polong/sampel (polong), berat polong/sampel ( $\mathrm{g}$ ), berat polong/plot $(\mathrm{kg})$

\section{Hasil \\ Tinggi Tanaman (cm)}

Hasil 14 hari setelah tanam (hst) sampai 63 hst Tabel 1. Pengaruh dosis kandang ayam pengamatan I (14 hst) belum menunjukkan pengaruh yang nyata $(\mathrm{p}<0.05)$ sampai umur tanaman 35 hst. Pengaruh perlakuan dosis pupuk kandang ayam beda nyata $(\mathrm{p}>0.05)$ pengamatan ke 42 sampai pengamatan 63 hari. Kontrol (Ao) paling rendah dibandingkan $A_{1}, A_{2}$ dan $A_{3}$. Pengaruh kandang ayam
14 hst sampai 63 hst lebih cepat, Gambar 1. dosis $300 \mathrm{~g} / \operatorname{tanaman}\left(\mathrm{A}_{2}\right) 63 \mathrm{hst}$ rata-rata $175.0 \mathrm{~cm}$. Dosis $400 \mathrm{~g} /$ tanaman $\left(\mathrm{A}_{3}\right)$ rata-rata $176.0 \mathrm{~cm}$ pengaruh tidak nyata ( $\mathrm{p}<0.05$ ), dosis terrendah 200 g/tanaman $\left(\mathrm{A}_{1}\right)$ rata-rata $174.2 \mathrm{~cm}$ beda tidak nyata terhadap $\mathrm{A}_{2}(\mathrm{p}<0.05)$. Tanpa pupuk kandang ayam (Ao) terrendah ratarata $172.7 \mathrm{~cm}$ beda nyata terhadap $\mathrm{A}_{1}, \mathrm{~A}_{2}$ dan $A_{3}$. Dosis anjuran 300 gram/tanaman $\left(\mathrm{A}_{2}\right)$, hasil analisa ada korelasi dosis pupuk kandang ayam terhadap pertumbuhan tinggi tanaman persamaan liniernya dengan $\mathrm{Y}=0.005 \mathrm{~A}+173.1$ dan dengan $\mathrm{r} 2=0.98$, gambar 2 . Tabel 1 . petumbuhan 14 hst belum pengaruh yang nyata $(\mathrm{p}<0.05)$ sampai 35 hst beda nyata 42 hst sampai 63 hst gambar 3. Terlihat 63 hst konsentrasi kontrol (Ko) pertumbuhan terrendah dibandingkan dengan konsentrasi pemberian air kelapa.

Air kelapa 63 hst $200 \mathrm{ml} /$ tanaman $\left(\mathrm{K}_{2}\right)$ rata-rata $175.1 \mathrm{~cm} .300 \mathrm{ml} /$ tanaman $\left(\mathrm{K}_{3}\right)$ rata-rata $176.0 \mathrm{~cm}$ pengaruh tidak nyata $(\mathrm{p}<0.05)$ terhadap $\mathrm{K}_{2}$, terrendah $100 \mathrm{ml} /$ tanaman $\left(\mathrm{K}_{1}\right)$ rata-rata $174.2 \mathrm{~cm}$ beda tidak nyata terhadap $\mathrm{K}_{2}(\mathrm{p}<0.05)$. Tanpa air kelapa $(\mathrm{Ko})$ terrendah rata-rata $172.6 \mathrm{~cm}$ beda nyata terhadap $\mathrm{K}_{1}, \mathrm{~K}_{2}$ dan $\mathrm{K}_{3}$. Konsentrasi anjuran $200 \mathrm{ml} /$ tanaman $\left(\mathrm{K}_{2}\right)$.

Tabel 1. Rata-rata tinggi Tanaman $(\mathrm{cm})$ dari Pengaruh pemberian dosis pupuk kandang ayam dan penggunaan dosis air kelapa pada tanaman Arcis

\begin{tabular}{|c|c|c|c|c|c|c|c|c|}
\hline \multirow{2}{*}{ Perlakuan } & \multicolumn{2}{|c|}{ Pengamatan } & \multicolumn{4}{|c|}{ (Hari setelah tanam) } & \multirow[b]{2}{*}{56} & \multirow[b]{2}{*}{63} \\
\hline & 14 & 21 & 28 & 35 & 42 & 49 & & \\
\hline Ao & $15.8 \mathrm{a}$ & $26.0 \mathrm{a}$ & $52.4 \mathrm{a}$ & $81.7 \mathrm{a}$ & $109.9 \mathrm{c}$ & $136.3 \mathrm{c} \quad 1$ & $153.7 \mathrm{c}$ & $172.7 \mathrm{c}$ \\
\hline A1 & $15.5 \mathrm{a}$ & $26.3 \mathrm{a}$ & $52.8 \mathrm{a}$ & $81.9 \mathrm{a}$ & $110.6 \mathrm{bc}$ & $137.0 \mathrm{bc} 1$ & $154.7 \mathrm{~b} \quad 1$ & $174.2 b$ \\
\hline $\mathrm{A} 2$ & $15.7 \mathrm{a}$ & $26.3 \mathrm{a}$ & $52.8 \mathrm{a}$ & $82.1 \mathrm{a}$ & $110.8 \mathrm{ab}$ & $137.7 \mathrm{ab} 1$ & $155.0 \mathrm{ab} 1$ & $175.0 \mathrm{ab}$ \\
\hline A3 & $15.4 \mathrm{a}$ & $26.5 \mathrm{a}$ & $53.0 \mathrm{a}$ & $82.4 \mathrm{a}$ & $111.1 \mathrm{a}$ & $138.3 \mathrm{a} \quad 1$ & $155.8 \mathrm{a}$ & $176.0 \mathrm{a}$ \\
\hline Ko & $15.4 \mathrm{a}$ & $25.9 \mathrm{a}$ & $52.4 \mathrm{a}$ & $81.6 \mathrm{a}$ & $109.8 \mathrm{c}$ & $136.2 \mathrm{c}$ & $153.6 \mathrm{c}$ & $172.6 \mathrm{c}$ \\
\hline K1 & $15.8 \mathrm{a}$ & $26.2 \mathrm{a}$ & $52.6 \mathrm{a}$ & $81.8 \mathrm{a}$ & $110.5 b c$ & $136.9 \mathrm{bc}$ & $154.7 b$ & $174.2 b$ \\
\hline $\mathrm{K} 2$ & $15.5 \mathrm{a}$ & $26.4 \mathrm{a}$ & $52.9 \mathrm{a}$ & $82.1 \mathrm{a}$ & $110.8 \mathrm{ab}$ & 137.7ab & $155.1 \mathrm{ab}$ & o $175.1 \mathrm{ab}$ \\
\hline K3 & $15.8 \mathrm{a}$ & $26.6 a$ & $53.1 \mathrm{a}$ & $82.6 \mathrm{a}$ & $111.3 \mathrm{a}$ & $138.5 \mathrm{a}$ & $155.9 \mathrm{a}$ & $176.0 \mathrm{a}$ \\
\hline
\end{tabular}

Keterangan : Huruf yang sama pada kolom perlakuan yang sama berbeda tidak nyata pada taraf $5 \%$.

Konsentrasi tinggi meningkatkan tinggi tanaman, hasil analisa ada korelasi persamaan liniernya dengan $\mathrm{Y}=0.007 \mathrm{~K}+173.2$ dan dengan $\mathrm{r}^{2}=0.97$, Gambar 4 . 


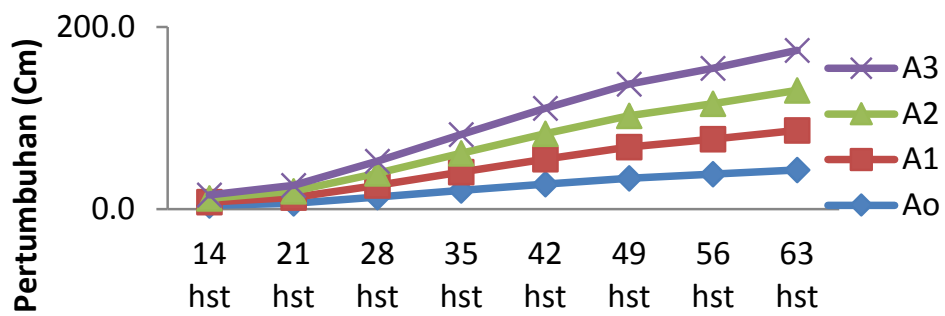

Gambar 1. Pengamatan (hst)

Gambar 1. Tinggi tanaman Arcis dari pengaruh pemberian pupuk kandang ayam

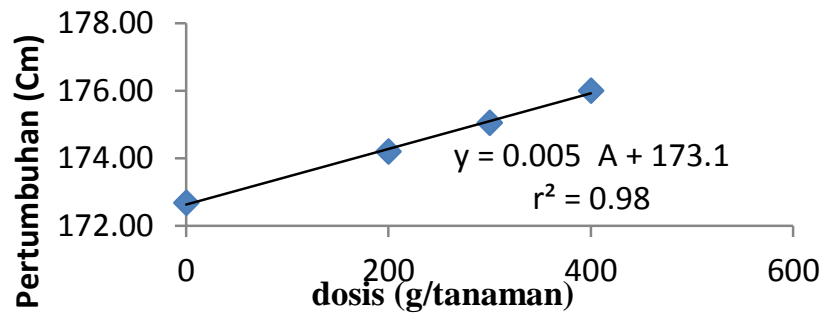

Gambar 3. Pengaruh penggunaan dosis pupuk kandang ayam terhadap tinggi tanaman ercis

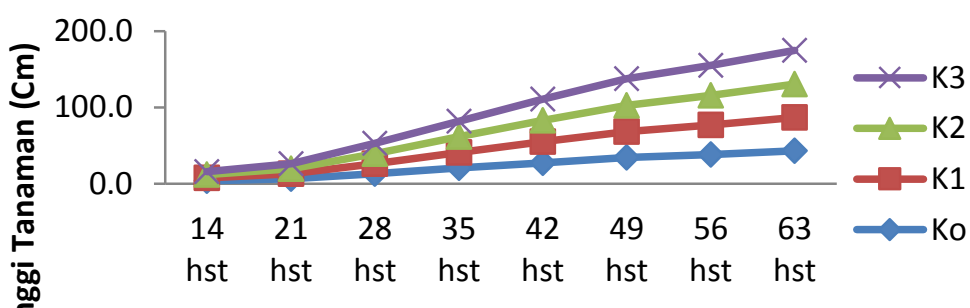

Gambar Pengamatan (hst) pengaruh pemberian pupuk kandang ayam

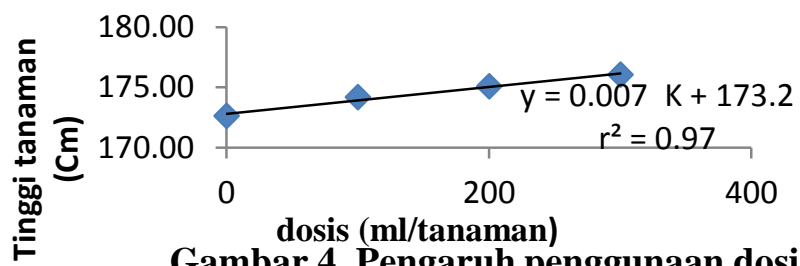

Gambar 4. Pengaruh penggunaan dosis air kelapa terhadap tinggi tanaman Arcis

Pengaruh interaksi berbeda tidak nyata $(\mathrm{p}$ $<0.05$ ). tinggi pupuk kandang ayam 300 $\mathrm{g} /$ tanaman dengan air kelapa 200 $\mathrm{ml} /$ tanaman $\left(\mathrm{A}_{2} \mathrm{~K}_{2}\right)$ tinggi tanaman ratarata $176.85 \mathrm{~cm}$. Sedangkan pertumbuhan paling rendah diperoleh dengan tanpa pupuk kanadang ayam dan air kelapa (AoKo) dengan tinggi tanaman paling rendah rata-rata $168.23 \mathrm{~cm}$.

\section{Jumlah Cabang}

Hasil analisa statistik jumlah cabang produktif Tabel 2. Dosis $400 \mathrm{~g} / \mathrm{tanaman}$ $\left(\mathrm{A}_{3}\right)$ paling banyak rata-rata 4.88 cabang berbeda nyata $(\mathrm{p}>0.05)$ terhadap perlakuan lainnya. Dosis $300 \mathrm{~g} /$ tanaman $\left(\mathrm{A}_{2}\right)$ rata-rata 4.53 cabang lebih sedikit berbanding dengan A3, keduanya memberikan pengaruh yang nyata $(\mathrm{p}>$ $0.05)$. 
Tabel 2. Rata-rata jumlah cabang tanaman arcis dari pengaruh dosis pupuk kandang ayam dan air kelapa.

\begin{tabular}{|c|c|c|c|c|c|}
\hline Perlakuan & Ao & $\mathbf{A}_{1}$ & $\mathbf{A}_{2}$ & $\mathbf{A}_{3}$ & Rata-rata \\
\hline Ко & 2.60 & 3.13 & 3.67 & 3.73 & $3.28 \mathrm{~d}$ \\
\hline $\mathbf{K}_{1}$ & 2.93 & 3.53 & 4.27 & 4.73 & $3.87 \mathrm{c}$ \\
\hline $\mathbf{K}_{2}$ & 3.20 & 4.13 & 5.00 & 5.60 & $4.48 \mathrm{~b}$ \\
\hline $\mathbf{K}_{3}$ & 3.53 & 4.87 & 5.20 & 5.47 & $4.77 \mathrm{a}$ \\
\hline
\end{tabular}

$\begin{array}{lllll}\text { Rata-rata } & 3.07 \mathrm{~d} \quad 3.92 \mathrm{c} & 4.53 \mathrm{~b} & 4.88 \mathrm{a}\end{array}$

Keterangan: Huruf yang sama pada baris atau kolom rata-rata yang sama berbeda tidak nyata pada taraf $5 \%$.

Dosis paling rendah $200 \mathrm{~g} / \operatorname{tanaman}\left(\mathrm{A}_{1}\right)$ lebih sedikit A1 rata-rata 3.92 cabang. Tanpa pupuk kandang ayam (Ao) ratarata 3.07 cabang, berbeda nyata terhadap perlakuan lain.
Dosis semakin tinggi menghasilkan jumlah cabang semakin banyak. Hasil analisa statistic kurva respon persamaan linier dengan $\mathrm{Y}=0.004 \mathrm{~A}+3.054$ dan $\mathrm{r}^{2}$ $=0.99$ Gambar 5 .

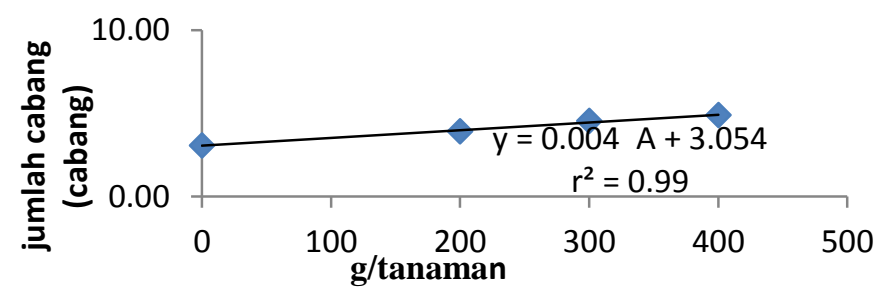

Grafik 5. Hubungan penggunaan dosis pupuk kandang ayam terhadap pertambahan...

Konsentrasi air kelapa pengaruh beda nyata $(\mathrm{p}>0.05)$ jumlah cabang. Air kelapa sebagai perangsang tumbuh konsentrasi $300 \mathrm{ml} / \operatorname{tanaman}\left(\mathrm{K}_{3}\right)$ rata-rata 4.77 cabang. Konsentrasi $200 \mathrm{ml} /$ tanaman $\left(\mathrm{K}_{2}\right)$ rata-rata 4.48 cabang berbeda nyata terhadap semua perlaakuan $(\mathrm{p}>0.05) . \mathrm{K}_{1}$ rata-rata 3,87 cabang beeda nyata dengan $\mathrm{K}_{2}$. $\mathrm{K}_{3}$ dan $\mathrm{K}_{0}$. Tanpa air kelapa $(\mathrm{Ko})$ paling sedikit rata-rata 3.28 cabang, dengan berbeda nyata terhadap perlakuan lain. Semakin tinggi dosis yang diberikan menghasilkan jumlah cabang semakin banyak. Berdasarkan hasil analisa statistic kurva respon berdasarkan persamaan linier dengan $\mathrm{Y}=0.005 \mathrm{~K}+3.34$ dan $\mathrm{r}^{2}=$ 0.98, Gambar 6 .

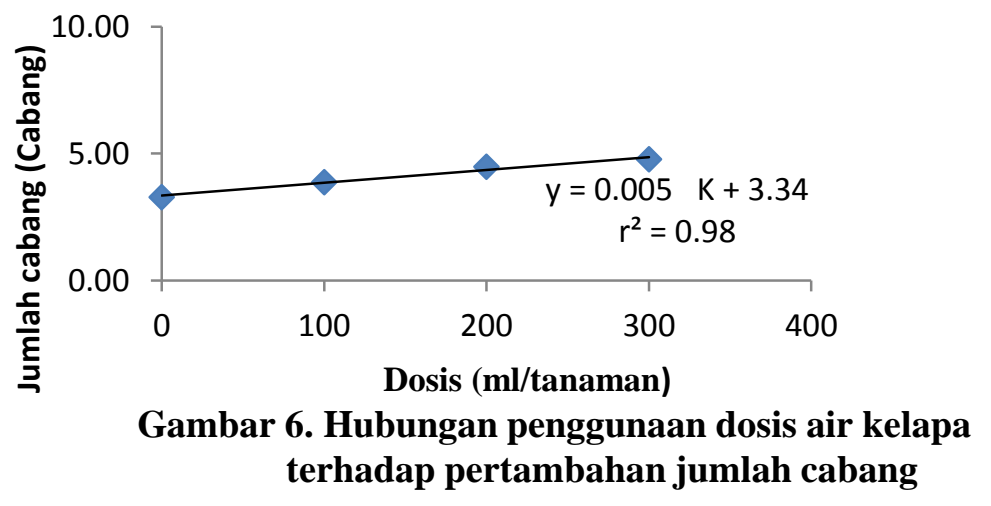


Agroteknosains/Vol.3/No. 02/November 2019/p-ISSN: 2598-6228/ e-ISSN : 2598-009

Pengaruh interaksi berbeda tidak nyata ( $\mathrm{p}<0.05)$. Pupuk kandang ayam 300 $\mathrm{g} /$ tanaman dengan air kelapa pada 200 $\mathrm{ml} / \operatorname{tanaman}\left(\mathrm{A}_{2} \mathrm{~K}_{2}\right)$ rata-rata 5.0 cabang.

\section{Umur Berbunga}

Umur berbunga terdapat perbedaan yang tidak nyata $(\mathrm{p}<0.05)$ berdasarkan analisa statistik dengan rata-rata Tabel 3. Umur mulai berbunga tidak berbeda nyata $(\mathrm{p}<$ 0.05) air kelapa. Tercepat berbunga tanpa pupuk (Ao) rata-rata 46.6 hari, umur berbunga lebih tinggi rata-rata 47.25 hari, kedua perlakuan beda umur yang kecil.

Tabel 3. Rata-rata umur berbunga dari pengaruh dosis pupuk kandang ayam dan air kelapa (hst).

\begin{tabular}{|c|c|c|c|c|c|}
\hline Perlakuan & Ao & $\mathbf{A}_{1}$ & $\mathbf{A}_{2}$ & $\mathbf{A}_{3}$ & Rata-rata \\
\hline Кo & 46.40 & 47.07 & 46.27 & 46.47 & $46.55 \mathrm{a}$ \\
\hline $\mathbf{K}_{1}$ & 6.53 & 6.73 & 46.27 & 47.00 & $46.63 a$ \\
\hline $\mathbf{K}_{\mathbf{2}}$ & 46.73 & 46.00 & 47.93 & 47.60 & $47.07 \mathrm{a}$ \\
\hline $\mathbf{K}_{3}$ & 46.73 & 46.73 & 47.67 & 47.93 & $47.27 \mathrm{a}$ \\
\hline
\end{tabular}

$\begin{array}{lllll}\text { Rata-rata } & 46.60 \mathrm{a} & 46.63 \mathrm{a} & 47.03 \mathrm{a} & 47.25 \mathrm{a}\end{array}$

Keterangan : Huruf yang sama pada kolom atau baris rata-rata yang sama berbeda tidak nyata pada taraf $5 \%$.

Air kelapa tidak mempengaruhi umur berbunga ( $\mathrm{p}<0.05)$, umur berbunga paling cepat tanpa air kelapa (Ko) ratarata 46.55 hari, sedangkan tertinggi pemberian air kelapa pada $300 \mathrm{ml} /$ tanaman $\left(\mathrm{K}_{3}\right) \quad$ rata-rata 47.27 hari, semua perlakuan konsentrasi berbeda tidak nyata $(\mathrm{p}<0.05)$. Perlakuan interaksi tidak pengaruh yang nyata. Hal ini terlihat bahwa dengan semakin tingginya dosis pupuk kandang ayam dan diikuti dengan dosis air kelapa akan memberikan umur berbunga semakin lambat.

\section{Jumlah Polong/Sampel (polong)}

Data analisa statistik tanaman arcis pengaruh dosis pupuk kandang ayam dan konsentrasi air kelapa terhadap jumlah polong/sampel beda nyata $(\mathrm{p}>0.05)$ tabel 5.

Tabel 5. Rata-rata jumlah polong/sampel tanaman Ercis dari pengaruh dosis pupuk kandang ayam dan air kelapa.

\begin{tabular}{cccccc} 
Perlakuan & Ao & $\mathrm{A}_{1}$ & $\mathrm{~A}_{2}$ & $\mathrm{~A}_{3}$ & Rata-rata \\
\hline $\mathrm{yo}$ & 29.63 & 29.41 & 35.86 & 51.11 & $36.50 \mathrm{c}$ \\
$\mathrm{K}_{1}$ & 38.72 & 46.79 & 50.01 & 63.21 & $49.68 \mathrm{~b}$ \\
$\mathrm{~K}_{2}$ & 36.52 & 46.27 & 57.71 & 63.14 & $50.91 \mathrm{ab}$ \\
$\mathrm{K}_{3}$ & 39.60 & 59.25 & 59.77 & 70.33 & $57.24 \mathrm{a}$
\end{tabular}

Rata-rata $\quad 36.12 \mathrm{c} \quad 45.43 \mathrm{~b} \quad 50.84 \mathrm{~b} \quad 61.95 \mathrm{a}$

Keterangan : Huruf pada kolom atau baris rata-rata yang sama berbeda tidak nyata pada taraf $5 \%$.

Hasil polong/sampel analisa statistik beda nyata $(\mathrm{p}>0.05)$, dipengaruhi dosis pupuk kandang ayam, semakin tinggi dosis hasil menaik. Dosis $400 \mathrm{ml} / \operatorname{tanaman}\left(\mathrm{A}_{3}\right)$ jumlah polong/sampel tertinggi rata-rata 61.65 polong, dosis $300 \mathrm{~g} / \operatorname{tanaman}\left(\mathrm{A}_{2}\right)$ jumlah polong/sampel rata-rata 50.84 polong berbeda nyata terhadap $\mathrm{A}_{3}$ dan dosis $200 \mathrm{~g} /$ tanaman $\left(\mathrm{A}_{1}\right)$ rata-rata jumlah polong/sampel lebih rendah 45.43 polong berbeda tidak nyata terhadap $\mathrm{A}_{2}(\mathrm{p}$ $<0.05)$, tetapi berbeda nyata terhadap $\mathrm{A}_{3}$ 
( $\mathrm{p}>0.05$ ). Dari Tabel 6. disimpulkan dosis pupuk kandang ayam yang tepat 400 g/tanaman $\left(\mathrm{A}_{3}\right)$ menghasilkan jumlah polong paling banyak. Perlakuan tanpa pupuk kandang ayam $($ Ao $=$ kontrol $)$ paling rendah rata-rata 36.12

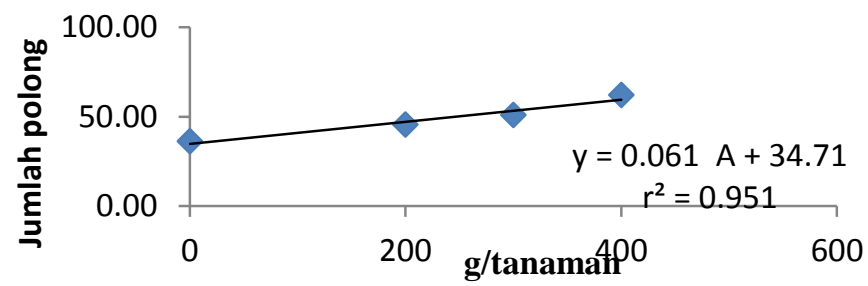

Gambar 9. Hubungan pemberian dosis pupuk kandang ayam terhadap jumlah polong yang dihasilkan

Konsentrasi Air kelapa hasil jumlah polong/sampel pengaruh beda nyata $(\mathrm{p}>0.05)$. Hasil tertinggi rata-rata 57.24 polong konsentrasi air kelapa 300 $\mathrm{ml} / \mathrm{tanaman}\left(\mathrm{K}_{3}\right)$, konsentrasi 200 $\mathrm{ml} /$ tanaman $\left(\mathrm{K}_{2}\right)$ dengan produksi polong rata-rata 50.91 polong per tanaman. Keduanya pengaruh tidak nyata $(\mathrm{p}<0.05)$ dan penggunaan dosis air kelapa 100 $\mathrm{ml} /$ tanaman $\left(\mathrm{K}_{1}\right)$ hasil rata-rata 49.68 0.89, Gambar 10. polong/sampel, berbeda nyata terhadap $\mathrm{A}_{1}, \mathrm{~A}_{2}$ dan $\mathrm{A}_{3}$.

Hasil analisa statistik kurva respon dengan persamaan $\mathrm{Y}=0.061 \mathrm{~A}+34.71$ dengan $r^{2}=0.95$, gambar 9 .

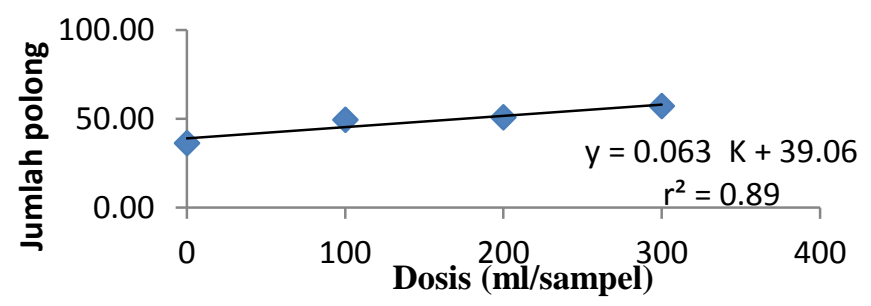

Gambar 10. Hubungan pemberian dosis air kelapa terhadap jumlah polong tanaman Arcis

Pengaruh interaksi tidak nyata terhadap Hasil analisa statistik tanaman arcis jumlah polong/sampel.

Berat Polong/sampel (g)

polong/sampel, terrendah dibandingkan dengan air kelapa yang lebih tinggi tetapi $\mathrm{K}_{1}$ perbedaan tidak nyata $\mathrm{K}_{2}(\mathrm{p}<0.05)$. Dibandingkan dengan tanpa air kelapa (Ko) hasil polong terrendah rata-rata 36.5 polong berbeda nyata terhadap pemberian semua konsentrasi air kelapa.

Hasil analisa memiliki korelasi pada persamaan $\mathrm{Y}=0.063 \mathrm{~K}+39.06$ dan $\mathrm{r}^{2}=$

Tabel 4. Rata-rata berat polong/tanaman (gram) arcis dari pengaruh
a dosis pupuk kandang ayam dan air kelapa.

\begin{tabular}{lccccc}
\hline Perlakuan & Ao & $\mathbf{A}_{1}$ & $\mathbf{A}_{\mathbf{2}}$ & $\mathbf{A}_{\mathbf{3}}$ & Rata-rata \\
\hline $\mathbf{K o}$ & & 2.69 & 2.67 & 3.264 .65 & $3.32 \mathrm{c}$ \\
$\mathbf{K}_{\mathbf{1}}$ & & 3.52 & 4.25 & 4.555 .75 & $4.52 \mathrm{~b}$ \\
$\mathbf{K}_{\mathbf{2}}$ & & 3.32 & 4.21 & 5.255 .74 & $4.63 \mathrm{ab}$ \\
$\mathbf{K}_{3}$ & & 3.60 & 5.39 & 5.436 .39 & $5.20 \mathrm{a}$ \\
\hline Rata-rata & $3.28 \mathrm{c}$ & $4.13 \mathrm{~b}$ & $4.62 \mathrm{~b}$ & $5.63 \mathrm{a}$ &
\end{tabular}


Agroteknosains/Vol.3/No. 02/November 2019/p-ISSN: 2598-6228/ e-ISSN : 2598-009

Keterangan : Huruf pada kolom atau barir yang sama berbeda tidak nyata pada taraf $5 \%$.

Hasil polong/sampel analisa statistik perbedaan nyata $(\mathrm{p}>0.05)$, hasil berpengaruh dosis pupuk kandang ayam, berat polong/sampel tanaman Arcis semakin tinggi dosis pemberian dan hasil semakin tinggi. Data tabel 4. dosis tertinggi $400 \mathrm{~g} /$ tanaman $\left(\mathrm{A}_{3}\right)$ berat polong paling tinggi rata-rata 5.63 gram, selanjutnya dosis $300 \mathrm{~g} / \operatorname{tanaman}\left(\mathrm{A}_{2}\right)$ rata-rata 4.62 gram berbeda nyata terhadap A3 dan dosis rendah pada $200 \mathrm{~g} /$ tanaman $\left(\mathrm{A}_{1}\right)$ rata-rata produksi polong/sampel lebih rendah 4.13 gram, dengan berbeda tidak nyata terhadap A2 ( $\mathrm{p}<0.05)$, tetapi berbeda nyata terhadap A3 ( $p>0.05$ ). Perlakuan tanpa pupuk kandang ayam (Ao $=$ kontrol) polong paling rendah rata-rata 3.28 gram sampel, berbeda nyata terhadap $\mathrm{A}_{1}, \mathrm{~A}_{2}$ dan $\mathrm{A}_{3}$.

Pemberian dosis pupuk kandang ayam semakin tinggi meningkatkan produksi polong/sampel, hasil analisa statistik memberikan kurva respon berhubungan dengan persamaan $\mathrm{Y}=$ $0.005 \mathrm{~A}+3.156$ dengan $\mathrm{r}^{2}=0.96$, Gambar 7.

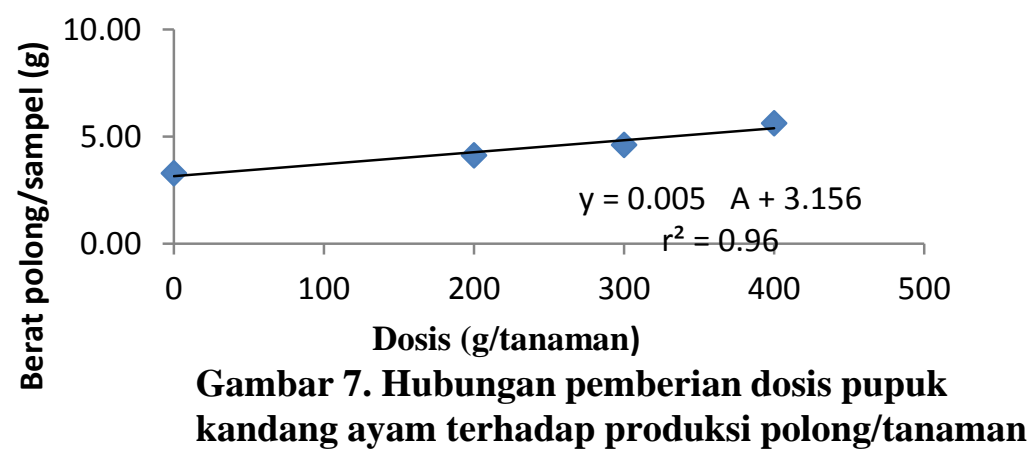

Air kelapa hasil polong tanaman/sampel beda nyata $(\mathrm{p}>0.05)$. Teringgi rata-rata 5.2 gram $300 \mathrm{ml} / \mathrm{tanaman}\left(\mathrm{K}_{3}\right)$, konsentrasi $200 \mathrm{ml} / \operatorname{tanaman}\left(\mathrm{K}_{2}\right)$ rata-rata 4.63 gram/tanaman, keduanya tidak memberikan pengaruh berbeda nyata $(\mathrm{p}<$ $0.05) \quad 100 \mathrm{ml} /$ tanaman $\left(\mathrm{K}_{1}\right)$ rata-rata 4.52 gram/tanaman, hasil terrendah dibandingkan konsentrasi air kelapa tertinggi tidak berbeda nyata terhadap $\mathrm{K}_{2}$ $(\mathrm{p}<0.05)$. Tanpa air kelapa $(\mathrm{Ko})$ hasil polong paling rendah rata-rata 3.32 gram berbeda nyata terhadap semua dosis air kelapa. Konsentrasi air kelapa menaik hasil polong/sampel semakin tinggi, hasil analisa statistik korelasi persamaan $\mathrm{Y}=$ $0.005 \mathrm{~K}+3.551$ dan $\mathrm{r}^{2}=0.89$ Gambar 8 . Pengaruh interaksi tidak bereda nyata hasil polong/sampel.

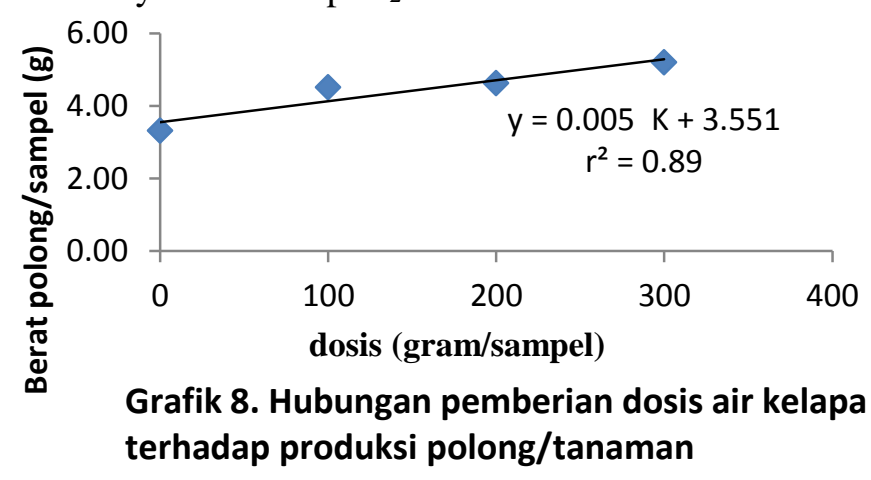

\section{Berat Polong per Plot (kg)}

Analisa statistik Tabel 6. hasil tanaman arcis dari pengaruh dosis pupuk kandang ayam dan konsentrasi air kelapa hasil polong/plot perbedaan yang nyata $(\mathrm{p}$ $>0.05$ ). 
Tabel 6. Rata-rata berat polong/plot Ercis dari pengaruh dosis pupuk kandang ayam dan air kelapa

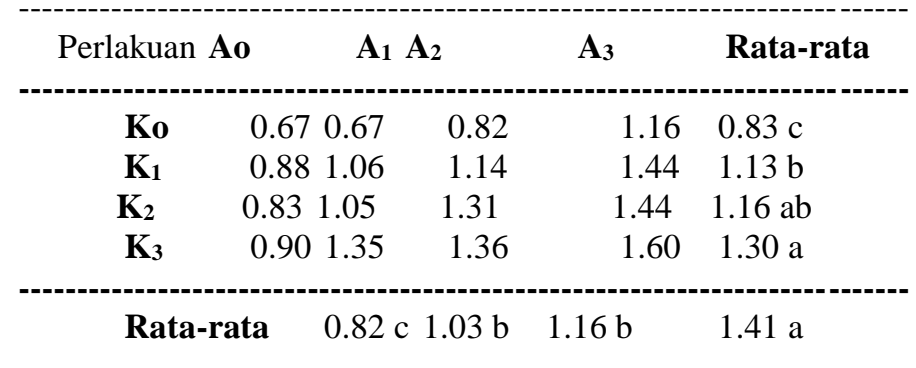

Keterangan : Huruf pada kolom atau baris rata-rata yang sama berbeda tidak nyata pada taraf $5 \%$.

Hasil polong/plot tanaman Ercis semakin tinggi apabila aplikasi dosis pupuk kandang ayam semakin tinggi. Dosis pupuk kandang ayam $400 \mathrm{~g} / \operatorname{tanaman}\left(\mathrm{A}_{3}\right)$ hasil polong/plot tertinggi rata-rata $1.41 \mathrm{~kg}$ beda nyata dengan $300 \mathrm{~g} / \operatorname{tanaman}\left(\mathrm{A}_{2}\right)$ rata-rata $1.16 \mathrm{~kg}$, dosis terrendah 200 $\mathrm{g} / \operatorname{tanaman}(\mathrm{A} 1)$ rata-rata $1.03 \mathrm{~kg}$ dan tanpa pupuk kandang ayam $(\mathrm{Ao}=$ kontrol $)$ rata-rata polong $0.82 \mathrm{~kg}$, berbeda nyata terhadap A1, A2 dan A3.

Pemberian pupuk kandang ayam respon hasil produksi polong/plot, semakin tinggi dosis pupuk kandang diberikan meningkatkan hasil polong/plot berdasarkan analisa statistik memberikan kurva respon dengan persamaan $\mathrm{Y}=0.001$
$\mathrm{A}+0.789$ dan $\mathrm{r}^{2}=0.97$, pada Gambar 11 . Pemberian air kelapa $300 \mathrm{ml} /$ tanaman rata-rata $1.3 \mathrm{~kg}$ per/plot $\left(\mathrm{K}_{3}\right)$, hasil paling tinggi beda tidak nyata terhadap perlakuan $\mathrm{K}_{2}$ drata-rata $1.16 \mathrm{~kg}$ dan $\mathrm{K}_{1} 1.13 \mathrm{~kg}$ per/plot. Perlakuan tanpa air kelapa (Ko) paling rendah rata-rata $0.83 \mathrm{~kg}$ berbeda nyata $\mathrm{K}_{3}, \mathrm{~K}_{2}$ dan $\mathrm{K}_{1}$. Konsentrasi air kelapa semakin tinggi hasil berat polong/plot y semakin tinggi, hasil analisa memiliki hubungan korelasi persamaan $\mathrm{Y}=0.063 \mathrm{~K}+39.06$ dan $\mathrm{r}^{2}=0.89$, Gambar 12. Semakin tinggi dosis pupuk organik kandang ayam konsentrasi air kelapa dapat meningkatkan penghasilan polong/plot tanaman kacang Arcis.

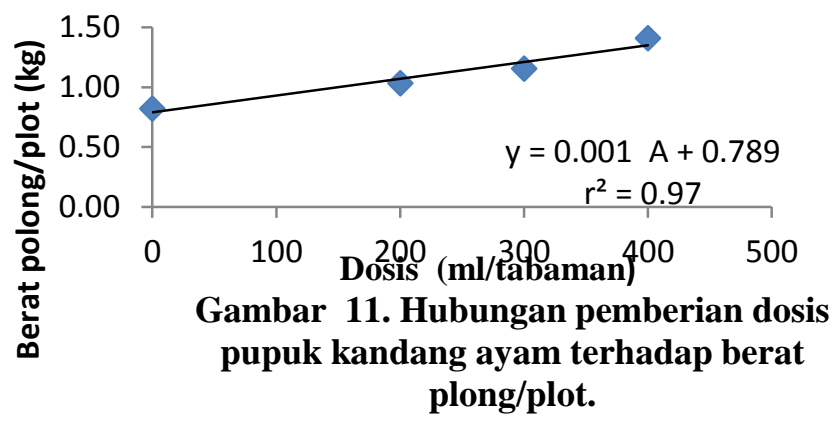




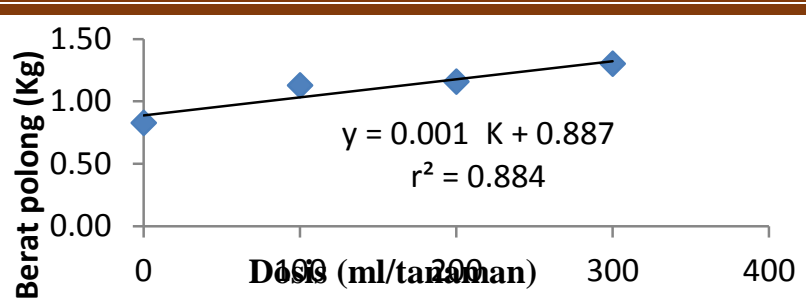

Gambar 12. Hubungan penggunaan dosis air kelapa terhadap berat polong/plot.

\section{Pembahasan \\ Pengaruh dosis pupuk kandang ayam dan air kelapa terhadap tinggi tanaman arcis}

Hasil analisis statistika pupuk kandang ayam dan air kelapa berpengaruh nyata terhadap tinggi tanaman setelah 42 hst. Pengaruh tidak nyata pada tinggi tanaman sejak tanaman 14 sampai 35 hari. Semakin tinggi dosis diberikan pada tanaman akan meni ngkatkan tinggi tanaman. Pupuk kandang ayam mengandung unsur $\mathrm{N}$ yang cukup tinggi pada pupuk kandang ayam sebanyak 1,80 $\%$, lebih tinggi dengan pupuk kandang yang lain seperti sapi hanya mengandung N sebanyak 0,51\% (Sutedjo, 2002).

Salah satu pupuk alami yang dapat meningkatan pertumbuhan vegetatif tanaman adalah air kelapa muda. Air kelapa merupakan cairan endosperm buah kepala yang mengandung senyawasenyawa biologi yang aktif. Menurut Winarto dkk. (2015:304), air kelapa mengandung komposisi kimia yang unik yang terdiri dari mineral, vitamin, gula, asam amino, dan fitohormon yang memilikiefek signifikan terhadap pertumbuhan tanaman.

\section{Pengaruh pupuk kandang ayam dan air kelapa jumlah cabang tanaman ercis}

Hasil pengamatan jumlah cabang produktif yang dilakukan dari lapangan dan hasil analisis diperoleh bahwa pengaruh dosis pupuk kandang ayam dan konsentras air kelapa berpengaruh nyata terhadap jumlah cabang. Semakin tinggi dosis pupuk organik dari kandang ayam maupun air kelapa yang diberikan pada tanaman dapat memperbanyak cabang pada tanaman Ercis. Hal ini disebabkan oleh pupuk kandang ayam maupun air kelapa mempunyai kandungan hara yang berpotensi sebagai penyedia unsur makro dan mikro yang diberikan melalui tanah. Pupuk kandang ayam mengandung unsur $\mathrm{N}$ yang cukup tinggi pada pupuk kandang ayam yaitu sebanyak 1,80 \%, lebih tinggi jika dibandingkan dengan pupuk kandang yang lain seperti sapi yang hanya mengandung $\mathrm{N}$ sebanyak 0,51\% (Sutedjo, 2002)

Hasil penelitian menunjukkan air kelapa dapat meningkatkan jumlah cabang, hal ini disebabkan air kelapa kaya akan unsure mineral yang diperlukan oleh tanaman seperti kandungan potasium (kalium), gula sebagai sumber karbon, protein dan mineral seperti natrium $(\mathrm{Na})$, kalsium $(\mathrm{Ca})$, magnesium $(\mathrm{Mg})$, ferum $(\mathrm{Fe})$, cufrum $(\mathrm{Cu})$, posfor $(\mathrm{P})$ dan sulfur $(\mathrm{S})$. Disamping kaya mineral, air kelapa juga mengandung berbagai macam vitamin seperti asam sitrat, asam nikotinat, asam pantotenal, asam folat, niacin, riboflafin dan thiamin (Anonim, 2010).

\section{Pengaruh pupuk kandang ayam dan air kelapa umur berbunga tanaman ercis}

Analisis statistik diperoleh bahwa pengaruh perlakuan penggunaan dosis pupuk kandang ayam dan dosis air kelapa tidak nyata. Hal ini disebabkan oleh pupuk kandang ayam maupun air kelapa walaupun mempunyai kandungan hara yang berpotensi sebagai penyedia unsur makro dan mikro kepada tanaman akan tetapi pertumbuhan umur berbunga memberikan perbedaan yang kecil. Pupuk organik yang diberikan mempunyai kandungan hara yang lebih tinggi jika dibandingkan dengan pupuk kandang yang lain seperti sapi yang hanya mengandung $\mathrm{N}$ sebanyak 0,51\% (Sutedjo, 2002). 
Pengaruh kandang ayam dan air kelapa Jumlah Polong/Sampel tanaman ercis

Data analisa statistik tanaman arcis pengaruh pupuk kandang ayam dan air kelapa terhadap jumlah polong/sampel beda nyata $(\mathrm{p}>0.05)$. Pupuk organik kandang ayam berpengaruh baik pertumbuhan dan hasil tanaman arcis. Air kelapa terdapat 2 hormon alami yaitu Auksin dan Sitokinin sebagai pendukung pembelahan sel embrio kelapa. Air kelapa sebagai pupuk tanaman cukup sederhana yaitu dengan menyemprotkan air kelapa pada daun dan siramkan pada akar (Wahyu , 2012).

Pengaruh pupuk kandang ayam dan air kelapa tberat polong/sampel tanaman ercis

Dosis pupuk kandang ayam dan air kelapa berat polong/sampel, hasil analisis statistk beda nyat $(p>0.05)$. Semakin tinggi dosis pupuk organik yang diberikan meningkatkan berat polong/sampel, penggunaan air kelapa terdapat pula 2 hormon alami yaitu Auksin dan Sitokinin sebagai pendukung pembelahan sel embrio kelapa. Cara penggunaan air kelapa sebagai pupuk tanaman cukup sederhana yaitu dengan menyemprotkan air kelapa pada daun dan siramkan pada akar (Wahyu , 2012).

Pengaruh pupuk kandang ayam dan air kelapa berat polong/Plot tanaman ercis

Pengaruh dosis pupuk kandang ayam dan air kelapa terhadap berat polong beda nyata $(\mathrm{p}>0.05)$. Potensi produktifitas tanah karena pupuk organik berupa pupuk kandang ayam dapat memperbaiki tekstur tanah, memperkaya/menambah unsur hara makro dan Mikro dan dapat mengembalikan kesuburan tanah (Anonim, 2010).

Penggunaan air kelapa terdapat pula 2 hormon alami yaitu Auksin dan Sitokinin sebagai pendukung pembelahan sel embrio kelapa. Cara penggunaan air kelapa sebagai pupuk tanaman cukup sederhana yaitu dengan menyemprotkan air kelapa pada daun dan siramkan pada akar (Wahyu , 2012).

\section{SIMPULAN DAN SARAN \\ Simpulan}

1. Pemberian pupuk kandang berpengaruh nyata tinggi tanaman, jumlah cabang, jumlah polong, berat polong/sampel dan berat polong/plot tanaman arcis. Dosis terbaik $300 \mathrm{~g} / \operatorname{tanaman}\left(\mathrm{A}_{2}\right)$,

2 .Air kelapa berpengaruh nyata tinggi tanaman, jumlah cabang, jumlah polong, berat polong/sampel dan berat polong/plot. Tidak beda nyata terhadap hari berbunga..

3. Interaksi dosis pupuk kandang ayam dan konsentrasi air kelapa memberikan pengaruh beda tidak nyata terhadap pertumbuhan dan hasil tanaman Arcis.

\section{Saran}

Perlu penelitian lebih lanjut dengan jenis pupuk kandang hewan lain, jenis tanaman yang berbeda, waktu dan tempat yang berbeda

\section{DAFTAR PUSTAKA}

Agampodi, V. A. dan Jayawardena, B. 2009. Effect of Coconut (Cocos nuciferaL.) Water Extractson Adventitious Root Development in Vegetative Propagation ofDracaenapurplecompactaL.A cta. Physiol. Plant, 31: 279284.

Anonimous. 2010. Aplikasi Pemupukan tanaman Kacangan. P.T. Meroke Tetap Jaya.

Anonimous, 2010a. Pupuk Hayati. Produk Ultramic (http://www.pupuk hayati.Co.id).

Anonimous. 2010. Kacang Kapri Organik. http://www.wikipedia.org/kapri.

Djamhuri, E. 2011. Pemanfaatan Air Kelapa untuk Meningkatkan Pertumbuhan Stek Pucuk MerantiTembaga (Shorea leprosulaMiq.).Jurnal Silvikultur Tropika, 2 (1): 5-8

Estu dan Nur. 1994. Budidaya Polong, Pucuk dan Baby Capri, Penebar Swadaya Jakarta. 
Agroteknosains/Vol.3/No. 02/November 2019/p-ISSN: 2598-6228/ e-ISSN : 2598-009

\begin{aligned} & \hline Kristina $\begin{array}{l}\text { dan Syahid, } 2012 \\ \text { Kultur Penelitian } \\ \text { Jaringan }\end{array} \\ &$ Temulawak,Universitas Negeri \\ & Padang,Padang. \\ & Mayadewi \\ & N.N.A. 2007. Pengaruh jenis \\ & pupuk kandang dan jarak \\ & tanam terhadap Pertumbuhan \\ & Gulma dan Hasil jagung manis \\ & (Tesis). Fakultas Pertanian \\ & Universitas Udayana. Den \\ & Pasar Bali - Indonesia. \end{aligned}

Pamungkas, F.T., Darmanti, S., dan Raharjo, B. 2009. Pengaruh Konsentrasi dan Lama Perendaman Dalam Supernatan Kultur Bacilus Sp.2 DUCCBR-KI 3 Terhadap Pertumbuhan Stek Horizontal Batang Jarak Pagar (Jatropha curcas L.). (Online). (http://eprints.undip.ac.id/2352/ 1/Publikasi Febri Jadi.pdf)

Peternak,Petani,Nelayan at 9:02AM infor masibudidaya.blogspot.com/20 11/0 3/budidayakapri.html,03/26/2011

Rukmana R.R. Pradsodjo, 2003. Usaha Tani Kapri, Kanisius, Yokyakarta.

Rukmana, 2006. Tanaman Kapri, Kanisius, Yokyakarta

Wahyu Posted at May 30, 2012 http://berkahcoconut.com /air-kelapa-sebagai-pupuktanaman/

Winarto, B. dkk. 2015. Use of Coconut Water and Fertilizer for In Vitro Proliferation and PlantletProduction of Dendrobium ' Gradita 3'.In Vitro Cell Development Biology Journal, 51:303-314 